\title{
Response of Forage Yield and its Components to Autumn and Spring Sowing Dates of Alfalfa (Medicago sativa)
}

\author{
Bakheit, B.R.; E.A. Teama; F.M. Fathy and "Asmaa A. Mohamed \\ Agronomy Department, Faculty of Agriculture, Assiut University \\ Email: Asmaa_ali@agr.aun.edu.eg \\ Received on: 7/2/2021 \\ Accepted for publication on: 9/2/2021
}

\section{Abstract}

This investigation was carried out at Agronomy Department Farm, Faculty of Agriculture, Assiut University, Egypt, to study the effect of temperature resulting from different sowing dates, genotypes and their interaction on forage yield and its components of alfalfa. A set of ten genotypes (Ismailia-1, Nubaria1, Ramah-1, populations from F.R.S., Kharja, El-Dahlia, Farafra, Balady and Aswan and Cuf 101) were sown on five sowing dates (three at autumn, October $10^{\text {th }}$ (D1), November $10^{\text {th }}$ (D2), December $10^{\text {th }}$ (D3), beside two at spring i.e. March $20^{\text {th }}$ (D4), April 20 ${ }^{\text {th }}$ (D5). Two experiments were carried out as experiment I (2017-2019) and experiment II (2018-2020). Each experiment included all autumn and spring sowing dates. The split block design with three replications was used in both experiments. Fifteen cuts were taken in the two years from each sowing date for each experiment. The results showed that the sowing dates and genotypes had highly significant effect on plant height, leaves/stem ratio, total fresh, dry and protein forage yields for the two experiments, except total protein forage yield in experiment I among studied genotypes which was non-significant. While, the interaction between sowing dates $\mathrm{x}$ genotypes insignificant for all studied traits in the two experiments. The highest mean values of plant height obtained from the plants sown in fourth (March D4) and fifth sowing dates (April D5) sowing date were in the two experiments. While, sowing at November (D2) and December (D3) gave the highest mean values of leaves/stems ratio.

Furthermore, the maximum total fresh, dry, protein forage yields were obtained from sowing at March $20^{\text {th }}$ (D4) in experiment I and from sowing on October $10^{\text {th }}$ (D1) in experiment II. It is remarkable results that the Ramah-1 genotype produced the highest total fresh, dry, and protein forage yields in the two experiments.

Finally, the correlations between forage yield and its components revealed that total protein forage yield was positive and significant correlated with fresh and dry forage yield, but negatively correlated with leaves/stems ratio in two experiments.

Keywords: Alfalfa, Medicago sativa, Sowing date, forage yield and its components.

\section{Introduction}

Alfalfa or Lucerne (Medicago sativa L.) is a highly productive forage legume of global importance. Being a long-lived perennial, it's had been called "The king of the Forages". It is one of the most important forage species in many countries for high production. In Egypt, the total cultivated area of alfalfa was about 73321 feddan (one feddan $=4200 \mathrm{~m}^{2}$ ) with an estimated productivity of about 1953422 tons of green fodder (B.A.S, 2018). It is one of the most 
important forage crops in terms of total area, economic value and energy efficiency. Because of alfalfa can fix nitrogen and synthesize protein, it is very useful to farmers, who have grown alfalfa as protein-rich fodder for cows, goats, sheep, chickens and others. It is cultivated over a wide range of climatic and edaphic conditions ranging from the semi-arid regions to the humid areas. Therefore, this crop plays a significant economic role in the market of animal feed (i.e. hay, dehydrated forage, pellets, and silage products) and a great effort have been made to improve its forage quality. Even, it has been an important agronomic feature in restoring soil structure by roots which create holes in the soil for air and water. Some farmers also used alfalfa plants as a green manure throughout plowing it into the soil for increment of soil fertility. Moreover, alfalfa needs only low fertilizer inputs and herbicides or pesticides, consequently, it has a positive public concern about the environmental impact of agricultural system. A propose of the other benefits i.e. some people consume alfalfa honey.

In Egypt, the production of forage crops did not satisfy the local requirements of animal feeding in summer season which are suffering from serious feed shortage and the receiving than their maintenance. Thus, it is very important to increase the production of alfalfa through, improving agricultural practices, selecting the adapted variety through suitable plant breeding program.

Current changes in the climatic conditions towards warming especially in Egypt are expected to pro- long the summer season and shorten the winter or any season during alfalfa grown. Thus, it was desirable to change the planting date of alfalfa to avoid the high or low temperature effects at the beginning of the fall season.

Forage yield and its components are often influenced by weather conditions at the reproductive period. Cakmakci et al. (2004) in Turkey found that the best sowing date of alfalfa was the last week of October. Mueller (2005) in U.S.A. reported that based upon temperature and day length information, fall planting dates were between September $15^{\text {th }}$ and October $31^{\text {st }}$ and spring planting dates between February $1^{\text {st }}$ and March $15^{\text {th }}$ which have the greatest potential for successful stand establishment. On the other hand, Abd El-Rady (2018) found all most the studied varieties had the highest seasonal fresh, dry, and protein forage yields when they were sown at December $20^{\text {th }}$ in both seasons. Abdel-Galil \& Hamed (2008) found significant differences among each of cultivars and years for all studied forage traits.

Variation in weather conditions at various stages of plant development may affect the different response of genotypes to environments. Because of alfalfa genotypes are being grown under a wide range of conditions, they are exposed to different soil types and fertility levels, moisture levels temperatures and cultural practices i.e. sowing date. All the variables encountered in producing alfalfa can be described collectively as the environment. Therefore, when the alfalfa genotypes are compared in different environments its perform- 
ance relative to each other may not be the same. These changes in the relative performance of genotypes across different environments are referred to as genotype $\mathrm{x}$ environment interaction.

Little information are available in Egypt regarding the influence of change in climatic conditions resulting from different planting dates on forage yield production of alfalfa

Therefore, the objectives of current study were 1- determine the influence of temperature conditions resulting from six different sowing dates on the forge yield production and its components of Egyptian alfalfa (Medicago sativa L.) genotypes under Assiut conditions, 2- study the nature of association between forage yield and their contributing variables via correlation coefficient.

\section{Materials and Methods}

This work was carried out at the Agronomy Department Experimental Farm, Faculty of Agriculture, Assiut University, Assiut, Egypt (27.19 N, $31.16 \mathrm{E}$; clay soil) during the three growing years from 2017 to 2020 in two experiments.

The physical and chemical properties of the experimental soil of experiment I and II (2017-2020) are clay $(49.4 \%)$, sand $(25.9 \%)$, silt (24.7\%), field capacity $(44.2)$, soil $\mathrm{pH}$ (7.80), organic matter $(1.62 \%)$, total nitrogen $(0.09 \%)$ and $\mathrm{CaCO}_{3}$ $(1.20 \%)$.

The materials for this study included nine genotypes from Egypt, namely: Ismailia-1, Nubaria-1, Ramah-1, Populations from F.R.S., Kharja, El-Dahlia, Farafra, Balady, Aswan beside one genotype introduced from U.S.A Cuf101.
Two experiments were carried out as experiment I (2017-2019) and experiment II (2018-2020). Treatments involved three autumn sowing dates, i.e. $10^{\text {th }}$ October $\left(D_{1}\right), 10^{\text {th }}$ November $\left(D_{2}\right)$ and $10^{\text {th }}$ December $\left(D_{3}\right)$; three spring sowing dates, i.e. $20^{\text {th }}$ March $\left(D_{4}\right), 20^{\text {th }}$ April $\left(D_{5}\right)$ and $20^{\text {th }}$ May $\left(D_{6}\right)$ and ten alfalfa genotypes for each experiment. The sowing date of $20^{\text {th }}$ May (D6) in both experiments did not germinated under Assiut condition.

Each experiment included all autumn and spring sowing dates, the split block design with three replications was used in both experiments. Sowing dates were arranged in vertical strips and the genotypes in horizental strips.

Plot size was one meter square (3 meters long x $33.5 \mathrm{~cm}$ ) for forage and its components. Alfalfa seed were broadcasted by hand at the rate of six and five $\mathrm{g} / \mathrm{m}^{2}$ (plot) for forage and seed yields, respectively.

All cultural practices were maintained at optimum level for maximum alfalfa productivity. Fifteen cuts were taken in the two years from each sowing date for each experiment.

\section{Data recorded}

\section{Forage yield and its components}

Data of the following traits were recorded at the time of each cut for each sowing date:

1- Mean plant height, (PH) cm: the mean of plant height in centimeter was determined at harvest for each cut as an average of 5 places measurement from soil surface to the tip of the tallest tiller, then the average of the fifteen cuts were taken for each experiment. 


\section{2- Mean leaves/stems ratio} (LS): A sample of fresh forage in each plot (200 g) was hand separated to leaves and stems. Each component was weighed immediately to estimate the fresh leaves/ stems ratio.

\section{3- Total fresh forage yield, $\mathrm{kg}$} (FFY): fresh forage yield, $\mathrm{kg} / \mathrm{plot}$ $\left(\mathrm{m}^{2}\right)$ was determined by hand clipping of each plot and the total of the fifteen cuts were taken for each sowing date for each experiment.

4- Dry matter percentage (DMP): it was determined from random samples of $150 \mathrm{~g}$ from each plot at each cut, after drying in an oven at $70^{\circ} \mathrm{C}$ until weight constancy. Then the mean of the fifteen cuts were taken for each experiment.

\section{5- Total dry forage yield} (DFY): estimated by using, green forage yield of each plot $\mathrm{x}$ means dry matter percentage.

6- Protein percentage (PP): it was determined in third cut for each sowing date and experiment in Lab. Qual. Procedure, Faculty of Agriculture, Assiut University by the microKjeldahl method as outlined by A.O.A.C. (1980) to estimate the total nitrogen. Nitrogen percentage was multiplied by 6.25 to obtained crude protein.

7- Total protein forage yield $\left(\mathbf{m}^{2}\right)$ (PY): estimated by using dry forage yield $/ \mathrm{m}^{2} \mathrm{x}$ protein percentage.

Climatic data during the period of growing seasons including maximum and minimum daily temperature, sun shine (Table 1) measured from sowing date to date of physiological maturity in each experiment and sowing date. The total growing degree days (GDD), (base= 7) was calculated for each sowing date according to Saeed and Francis (1984) as follows:

Total growing degree days $(\mathrm{GDD})=$

$\Sigma[(($ Maximum + Minimum temperature)/2)-7]

Where, $7=$ Zero growth point from sowing date to fifteen cuts.

\section{Statistical analysis:}

For forage yield and its components for five planting date over fifteen cuts, were performed according to Gomez and Gomez (1984). The variances of all studied traits between two experiments were detected and not homogeneity, consequently the combine analysis was not done. Means were compared using L.S.D. test at 5 and $1 \%$ levels of probability.

\section{Phenotypic correlations:}

The phenotypic correlation across sowing dates as well as genotypes in each of experiment-1 (2017 to 2019) and experiment-2 (2018 to 2020) for forage yield and their components, as well as over both forage and seed yield and their components were calculated among the studied traits as outlined by Walker (1960).

\section{Results and Discussion}

The sowing dates used to evaluate the genotypes performance in this study provided a range of variation in seasonal climate. The climatic conditions i.e. average temperature and photoperiod Sunshine Table 1 and the total Growing, Degree Days (GDD) were recorded different values during the two growing experiments for forage yield (Table 2 ). 
The obtained results could be illustrated as following:

\section{A- Forage yield and their compo- nents}

\section{A.1- Mean plant height}

Plant height is an essential factor in determining the forage yield for forage crops. Tuckak et al. (2008) reported that plant height is an important yield component and it is often used as a criterion when choosing superior genotypes in an early stage of selection. The analysis of variance for plant height indicated that planting dates and genotypes exerted a highly significant effects in both experiments (Table 3). But, plant dates $\mathrm{x}$ genotypes interaction had insignificant effects on this trait. One of the reason of this insignificant result may be due to, the estimated of plant height from the average of fifteen cuts for both experiments.

The variance of mean plant height between two experiments was detected and not homogeneity, consequently the combined analysis was not done.

The average of plant height in Experiment I and Experiment II for the five sowing dates and the ten genotypes are given in Table 4. The results revealed that the highest mean value of plant height were obtained from the plants sown in the fifth April (D5) and fourth March (D4) spring sowing dates, i.e. 83.07 and $77.97 \mathrm{~cm}$ in the Experiment I and II, respectively.

The comparisons also showed that plants sown at $10^{\text {th }}$ November (D2) produced the shortest plant height of 73.0 in Experiment I and $68.36 \mathrm{~cm}$ at $20^{\text {th }}$ April (D5) in Experiment II (Table 4). This could be due to climatological conditions prevailing during this period. 
Table 1. Mean of daily temperature $\left({ }^{\circ} \mathrm{C}\right)$ during the period of alfalfa growth from 2017 to 2020 years.

\begin{tabular}{|c|c|c|c|c|c|c|c|c|c|c|c|c|c|c|c|c|c|c|c|}
\hline \multirow{3}{*}{$\stackrel{\bar{E}}{\bar{E}}$} & \multirow{3}{*}{$\begin{array}{l}n \\
\stackrel{0}{0} \\
\stackrel{0}{0} \\
0\end{array}$} & \multicolumn{9}{|c|}{ Average temperature $\left({ }^{\circ} \mathrm{C}\right)$} & \multicolumn{9}{|c|}{ Sun shine } \\
\hline & & \multicolumn{3}{|c|}{$2017 / 2018$} & \multicolumn{3}{|c|}{ 2018/2019 } & \multicolumn{3}{|c|}{$2019 / 2020$} & \multicolumn{3}{|c|}{$2017 / 2018$} & \multicolumn{3}{|c|}{ 2018/2019 } & \multicolumn{3}{|c|}{$2019 / 2020$} \\
\hline & & . & 1. & an & 1 & in. & an & ax. & Min. & M & $\begin{array}{l}\begin{array}{l}\text { Sun } \\
\text { rise }\end{array} \\
\end{array}$ & Sun set & $\begin{array}{c}\text { Day } \\
\text { length }\end{array}$ & $\begin{array}{l}\text { Sun } \\
\text { rise }\end{array}$ & Sun set & $\begin{array}{c}\text { Day } \\
\text { length }\end{array}$ & $\begin{array}{l}\text { Sun } \\
\text { rise }\end{array}$ & et & $\begin{array}{c}\text { Day } \\
\text { length }\end{array}$ \\
\hline \multirow{3}{*}{ Oct. } & 01-10 & 32.40 & \begin{tabular}{|l|}
19.70 \\
\end{tabular} & 26.18 & 34.10 & 21.80 & \begin{tabular}{|l|}
27.46 \\
\end{tabular} & 35.60 & 21.80 & 28.44 & $5: 50: 30$ & $17: 39: 30$ & $11: 49: 00$ & $50: 30$ & $: 39: 48$ & $11: 49: 18$ & $50: 30$ & $40: 00$ & $11: 49: 30$ \\
\hline & $1-20$ & 28.80 & 16.00 & 22.17 & 30.60 & 16.20 & 23.52 & 34.60 & 19.60 & 26.75 & $5: 48$ & & 6 & $5: 36$ & & 54 & 0.50 & & 04.00 \\
\hline & $21-31$ & 34.60 & 15.00 & 21.89 & 31.70 & 16.40 & 24.46 & 29.40 & 17.20 & 22.91 & 6:02:05 & $8: 54$ & 6 & 6:01:49 & \begin{tabular}{|l|}
$9: 19: 27$ \\
\end{tabular} & $: 17: 38$ & $01: 44$ & & $1: 17: 55$ \\
\hline \multirow{3}{*}{ Nov. } & |01-10 & 25.10 & 12.70 & 18.38 & 28.50 & 14.40 & & 29.40 & 15.00 & 21.88 & 09:00 & & & 6:08:48 & & & & & \\
\hline & 11-20 & 26.90 & 11.20 & 18.57 & 24.80 & 12.20 & & 29.00 & 15.20 & 21.48 & $6: 16: 18$ & & & $: 00$ & & & & & \\
\hline & $21-30$ & 22.10 & 10.20 & 15.86 & 25.30 & 12.10 & & 26.00 & 11.80 & 18.16 & & & & & & & & & \\
\hline \multirow{3}{*}{ Dec. } & |01-10 & 23.00 & \begin{tabular}{|l|}
8.80 \\
\end{tabular} & 15.05 & 20.90 & \begin{tabular}{|l|}
8.90 \\
\end{tabular} & .64 & 22.40 & 11.10 & 16.28 & & & & & & & & & \\
\hline & $11-20$ & 23.80 & 9.60 & $\mid 16.21$ & 21.40 & 8.50 & .07 & 21.30 & 8.40 & 14.22 & & & & & & 06 & & & \\
\hline & $21-31$ & 20.80 & 9.10 & 14.49 & 19.30 & 7.50 & 2.91 & 19.50 & 5.90 & 12.44 & $43: 38$ & & & & & & & & $26: 27$ \\
\hline \multirow{3}{*}{ Jan. } & $01-10$ & 20.20 & \begin{tabular}{|l|}
7.50 \\
\end{tabular} & 13.24 & 17.90 & \begin{tabular}{|l|}
5.70 \\
\end{tabular} & 1.33 & 16.60 & \begin{tabular}{|l|}
5.60 \\
\end{tabular} & 10.61 & $46: 48$ & & & 48 & & & & & $: 29: 48$ \\
\hline & $11-20$ & 20.30 & 6.80 & 13.18 & 17.50 & 5.50 & 71 & 19.30 & 6.80 & 13.13 & 6:47:30 & & & & & & & & \\
\hline & $21-31$ & 18.00 & 40 & $\mid 11.76$ & 21.10 & 7.00 & & 18.60 & 5.40 & 51 & 16 & & & & & & & & \\
\hline \multirow{3}{*}{ Feb. } & |01-10 & 28.50 & 11.10 & 19.06 & 23.10 & \begin{tabular}{|l|}
8.20 \\
\end{tabular} & 57 & 19.90 & \begin{tabular}{|l|}
6.50 \\
\end{tabular} & 13.04 & 6:40:24 & & & 6 & & & & & \\
\hline & $11-20$ & 22.30 & 11.50 & 16.64 & 19.10 & 7.10 & 20 & 21.80 & \begin{tabular}{|l|}
8.30 \\
\end{tabular} & 14.81 & 30 & & & & & & & & \\
\hline & $21-29$ & 25.90 & 13.00 & 19.24 & 21.80 & 8.20 & 5.13 & 28.40 & 8.30 & 15.23 & $6: 25: 52$ & & & 07 & & $11: 28: 08$ & 53 & & 11:28:27 \\
\hline \multirow{3}{*}{ Mar. } & |01-10 & 31.80 & 15.50 & 23.44 & 22.40 & 7.60 & 4.63 & 25.50 & 9.80 & 18.04 & $17: 18$ & & & & & & & & \\
\hline & $11-20$ & 28.20 & 13.10 & 20.45 & 23.90 & 9.70 & 81 & 24.20 & 11.30 & 17.42 & 30 & & & & & & & & \\
\hline & $21-31$ & & & 22.25 & 26.70 & 12.70 & & 27.60 & 13.50 & & & & & & & & & & \\
\hline \multirow{3}{*}{ Apr. } & |01-10 & 28.20 & 13 & 2 & 27.40 & 12.40 & & 28.80 & 14.30 & 21 & & & & & & & & & \\
\hline & $11-20$ & 36.30 & 18.20 & 27.75 & 29.00 & 14.60 & 2 & 28.20 & 13.80 & 21.33 & 5:32:30 & & & -2 & & & & & \\
\hline & $21-30$ & 31.70 & 17.00 & 24.70 & 32.30 & 15.40 & 36 & 32.30 & 17.40 & 24.74 & 00 & & & & & & & & \\
\hline \multirow{3}{*}{ May. } & |01-10 & 37.70 & 22.60 & 29.72 & 34.00 & 20.30 & 26.73 & 32.90 & 17.00 & 25.30 & $5: 14: 48$ & 24 & & 06 & 24 & $13: 17: 18$ & 30 & $: 48$ & $13: 18: 18$ \\
\hline & $1-20$ & 35.60 & 19.80 & 26.98 & 36.30 & 22.00 & 29.41 & 39.50 & 22.40 & 31.12 & $5: 08: 12$ & $: 12$ & & 18 & $: 12$ & 54 & 06 & 36 & $0: 30$ \\
\hline & $21-31$ & & 24.20 & 3 & 41.40 & 24.70 & & 31.90 & 19.20 & & & & & & & & & & \\
\hline \multirow{3}{*}{ Jun. } & |01-10 & 0 & 70 & 2 & 38.90 & 24.60 & & 38.50 & 22.20 & 30.34 & & & & & & & & & \\
\hline & $11-20$ & 39.10 & 24.00 & 3 & 37.70 & 24.50 & & 38.10 & 23.40 & 30.72 & 5: & & & & & & & & \\
\hline & $21-30$ & 80 & 0 & 3 & 39.00 & 26.20 & & 37.80 & 23.60 & 77 & 48 & & & & & & & & \\
\hline \multirow{3}{*}{ Jul. } & |01-10 & 37.80 & 25.10 & 31.73 & 38.20 & 25.20 & 31.75 & 38.70 & 24.30 & 31.65 & $5: 06: 12$ & 00 & & $5: 06: 12$ & & $: 48$ & & & $9: 30$ \\
\hline & $11-20$ & 36.30 & 24.50 & 30.67 & 39.50 & 26.50 & 33.15 & 38.10 & 23.30 & 30.40 & $5: 10: 36$ & $18: 54: 12$ & $13: 4$ & $5: 10: 30$ & \begin{tabular}{|l|}
$18: 54: 18$ \\
\end{tabular} & $13: 43: 48$ & $5: 11: 00$ & 4:06 & $13: 43: 06$ \\
\hline & $21-31$ & 38.80 & 25.60 & 31.86 & 38.00 & 22.70 & 31.30 & 38.00 & 24.80 & 31.25 & $5: 16: 05$ & \begin{tabular}{|l|l|}
$18: 50: 00$ \\
\end{tabular} & $13: 33: 55$ & $5: 15: 55$ & 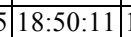 & 13:34:16 & $5: 16: 16$ & $: 44$ & $33: 27$ \\
\hline & |01-10 & 38.00 & 25.60 & 32.13 & 39.10 & 26.00 & 32.40 & 40.60 & 25.10 & 32.97 & $5: 21: 30$ & & & 30 & & $2: 06$ & & & $: 06$ \\
\hline Aug. & $1-20$ & 37.50 & 24.60 & 3 & 29.00 & 26.40 & 72 & 37.10 & 24.70 & 30.89 & $5: 27: 00$ & & & & & & & & \\
\hline & $21-31$ & 34.90 & 25.10 & 29.95 & 37.00 & 24.30 & 0 & 36.50 & 21.20 & 29.86 & 5:32:06 & & & & & & & & \\
\hline & $\mid 01-10$ & 36.10 & 23.90 & 29.79 & 36.30 & 21.60 & 92 & 36.40 & 23.8 & 30.22 & $36: 48$ & & & & & & & & \\
\hline ept. & $11-20$ & 34.40 & 21.70 & 27.24 & 34.10 & 22.10 & 28.19 & 38.00 & 30.57 & 21.90 & $5: 41: 12$ & & & $5: 4$ & & & $5: 4$ & & $0: 36$ \\
\hline & $21-30$ & 35.00 & 20.80 & 44 & 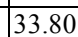 & 21.50 & 27.17 & 37.30 & 23.50 & 97 & & & & & & & & & . \\
\hline
\end{tabular}

Source: Meteorological authority, Assiut, Egypt.

Table 2. Total growing degree days (GDD) for each sowing date and season at Assuit where alfalfa trials were conducted.

\begin{tabular}{|l|c|c|}
\hline \multirow{2}{*}{ Sowing date } & \multicolumn{2}{c|}{ Forage yield from sowing date until fifteen cuts } \\
\cline { 2 - 3 } & $\mathbf{2 0 1 7 / 2 0 1 9}$ & $\mathbf{2 0 1 9} / \mathbf{2 0 2 0}$ \\
\hline $\mathbf{1 0}^{\text {th }}$ October & 7677 & 7395 \\
\hline $\mathbf{1 0}^{\text {th }}$ November & 7587 & 7181 \\
\hline $\mathbf{1 0}^{\text {th }}$ December & 7547 & 7260 \\
\hline $\mathbf{1 0}^{\text {th }}$ March & 8575 & 8373 \\
\hline $\mathbf{1 0}^{\text {th }}$ April & 8898 & 8773 \\
\hline
\end{tabular}

Data in Table 4 also showed that Ramah-1 over the five sowing dates gave the tallest plant height $(81.37 \mathrm{~cm})$ in both Experiments. While the Cuf 101 variety gave the shortest plant height $(73.23 \mathrm{~cm})$ over the Experiment I and II. These results may be due to the genetic variability among the tested genotypes and their different response under environmental conditions during the growing experiments which were suitable for 
Ramah-1 and Aswan population than the other tested genotypes. These results are in agreement with those reported by Abdel-Galil \& Hamed (2008), Hamd Alla (2012) and Abd El-Rady (2018), who found a significant difference among alfalfa genotypes and between years for plant height.

It could be noticed that the tallest plant of 88.05 and $87.16 \mathrm{~cm}$ were obtained by sowing Ramah-1 at the D1 and D5 in Experiment I. As well as the tallest plant height of 84.99 and $80.58 \mathrm{~cm}$ were obtained by sowing Aswan population at the April, $20^{\text {th }}$ (D5) in experiment I and October, $20^{\text {th }}$ (D1) in experiment II.

\section{A.2- Mean leaves/stems ratio:}

Leaves/stems ratio is one of the essential factors in determining the forage quality and palatability in for- age crops. The separate analysis of variance for leaves/stem ratio traits of the ten alfalfa genotypes at five sowing dates in the two experiments is shown in Table 3. The results showed that sowing dates as well as genotypes were highly significant in leaves/stems ratio for both experiments. This may be due to the difference between the two experiments in the climatic conditions (temperature, relative humidity and photoperiod). One of the reason of this insignificant may be due to, the estimated of leaves/stem ratio from average of fifteen cuts Table 5 .

The variance of mean leaves/stems ratio between two experiments was detected and was not homogeneity, consequently the combined analysis was not done.

Table 3. Analysis of variance for forage yield and its components of ten alfalfa genotypes under five different sowing dates in 2017-2019 (Exp. I) and 20182020 (Exp. II).

\begin{tabular}{|c|c|c|c|c|c|c|c|c|c|c|c|}
\hline \multirow{3}{*}{$\begin{array}{c}\text { Source of } \\
\text { variation }\end{array}$} & \multirow{3}{*}{ d.f } & \multicolumn{10}{|c|}{ Mean Squares } \\
\hline & & \multicolumn{2}{|c|}{$\begin{array}{l}\text { Average plant } \\
\text { height }(\mathrm{cm})\end{array}$} & \multicolumn{2}{|c|}{$\begin{array}{c}\text { Average } \\
\text { leaves/ } \\
\text { stems ratio } \\
\%\end{array}$} & \multicolumn{2}{|c|}{$\begin{array}{l}\text { Total fresh } \\
\text { forage yield } \\
\left(\mathbf{k g} / \mathbf{m}^{2}\right)\end{array}$} & \multicolumn{2}{|c|}{$\begin{array}{l}\text { Total dry for- } \\
\text { age yield } \\
\left(\mathbf{k g} / \mathbf{~ m}^{2}\right)\end{array}$} & \multicolumn{2}{|c|}{\begin{tabular}{|c} 
Total pro- \\
tein forage \\
yield \\
$\left(\mathbf{k g} / \mathbf{m}^{2}\right)$
\end{tabular}} \\
\hline & & Exp. I & Exp. II & $\begin{array}{c}\text { Exp. } \\
\text { I }\end{array}$ & \begin{tabular}{|c|} 
Exp. \\
II
\end{tabular} & Exp. I & Exp. II & Exp. I & Exp. II & \begin{tabular}{|c|} 
Exp. \\
I
\end{tabular} & $\begin{array}{c}\text { Exp. } \\
\text { II }\end{array}$ \\
\hline Replication & 2 & 20.17 & 10.74 & 0.01 & 0.02 & 53.10 & 69.29 & 3.19 & 3.67 & 0.11 & 0.23 \\
\hline Sowing date (D) & 4 & $630.98 * *$ & $385.92 * *$ & $0.23^{* *}$ & $0.31 * *$ & $2523.41 * *$ & $871.91^{\text {** }}$ & $118.25^{* *}$ & $40.93^{* *}$ & $5.31^{* *}$ & $3.78^{* *}$ \\
\hline Error (a) & 8 & 18.90 & 2.39 & 0.01 & 0.03 & 5.82 & 53.07 & 0.22 & 2.81 & 0.02 & 0.07 \\
\hline Genotype (G) & 9 & $83.28 * *$ & $128.33^{* *}$ & $0.06^{* *}$ & $0.09 * *$ & $36.19^{* *}$ & $73.87^{* *}$ & $1.73^{* *}$ & $3.96^{* *}$ & 0.13 & $0.17 * *$ \\
\hline Error (b) & 18 & 8.08 & 10.91 & 0.002 & 0.01 & 4.87 & 6.80 & 0.26 & 0.28 & 0.02 & 0.02 \\
\hline GXD & 36 & 12.95 & 7.58 & 0.005 & 0.01 & 8.43 & 18.15 & 0.41 & 0.81 & 0.04 & 0.07 \\
\hline Error (c) & 72 & 10.05 & 5.19 & 0.004 & 0.01 & 6.60 & 13.29 & 0.27 & 0.67 & 0.03 & 0.06 \\
\hline
\end{tabular}


Table 4. Mean plant height $(\mathrm{cm})$ of the ten alfalfa genotypes under each sowing dates in 2017-2019 (Exp. I) and 2018-2020 (Exp. II).

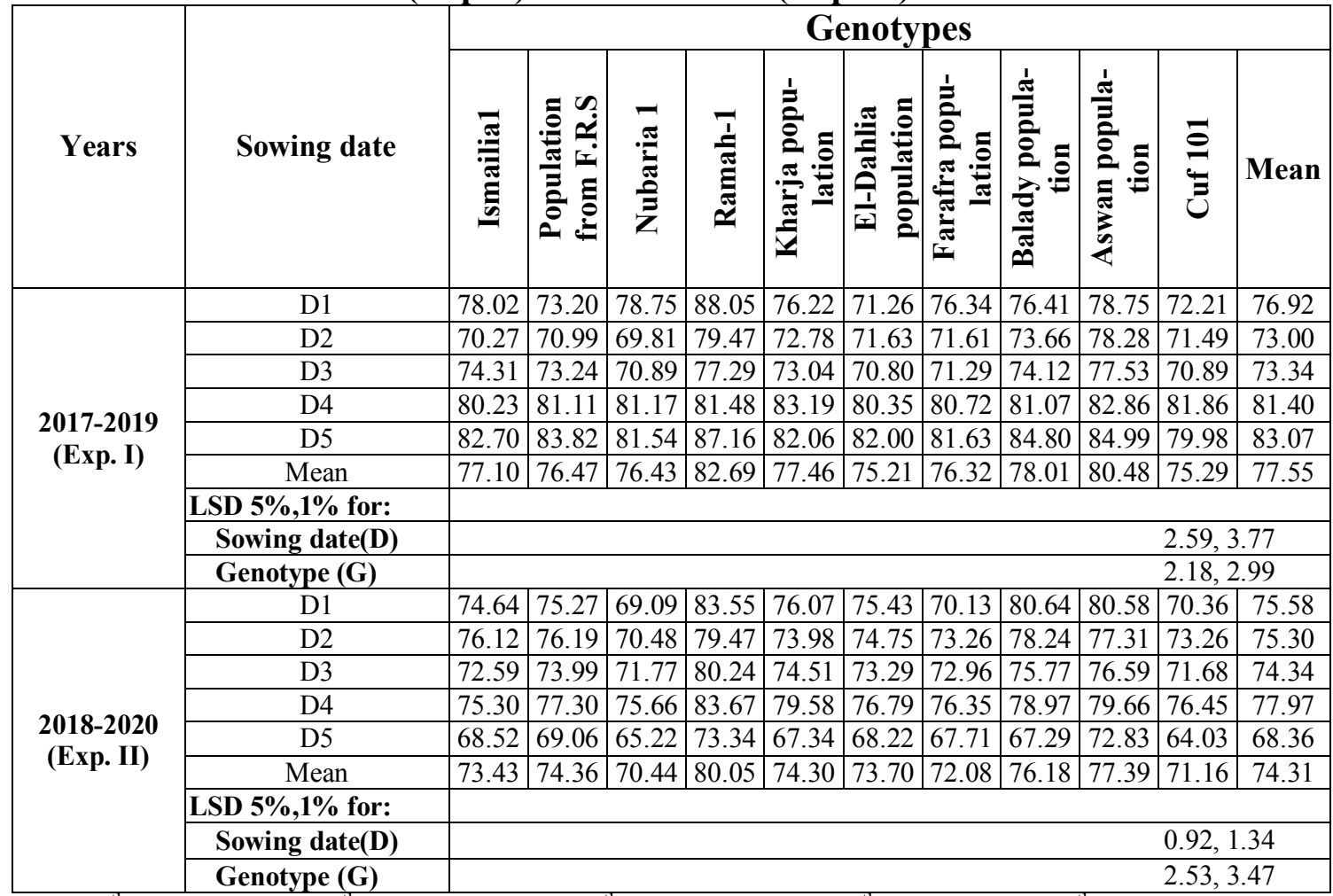

D1 $=10^{\text {th }}$ October, D2 $=10^{\text {th }}$ November, D3 $=10^{\text {th }}$ December, D4 $=20^{\text {th }}$ March, D5 $=20^{\text {th }}$ April, D1, D2 and D3 autumn sowing dates,

Table 5. Mean leaves/stems ratio \% of the ten alfalfa genotypes under each sowing dates in 2017-2019 (Exp. II) and 2018-2020 (Exp. II).

\begin{tabular}{|c|c|c|c|c|c|c|c|c|c|c|c|c|}
\hline \multirow[b]{2}{*}{ Years } & \multirow[b]{2}{*}{ Sowing date } & \multicolumn{11}{|c|}{ Genotypes } \\
\hline & & 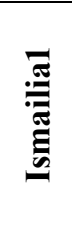 & 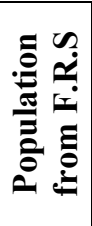 & 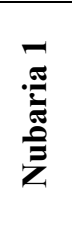 & 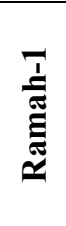 & 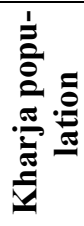 & 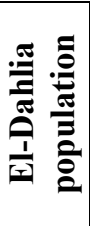 & 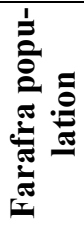 & 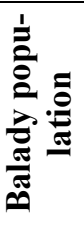 & 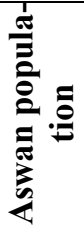 & $\underset{\Xi}{\vec{\Xi}}$ & Mean \\
\hline \multirow{9}{*}{$\begin{array}{c}\text { 2017-2019 } \\
\text { (Exp. I) }\end{array}$} & D1 & 1.18 & 1.22 & 1.23 & 1.01 & 1.16 & 1.24 & 1.08 & 1.05 & 1.03 & 1.26 & 1.15 \\
\hline & D2 & 1.28 & 1.29 & 1.29 & 1.12 & 1.24 & 1.25 & 1.25 & 1.13 & 1.11 & 1.32 & 1.23 \\
\hline & D3 & 1.26 & 1.31 & 1.27 & 1.11 & 1.17 & 1.31 & 1.28 & 1.17 & 1.14 & 1.28 & 1.23 \\
\hline & $\mathrm{D} 4$ & 1.08 & 1.07 & 1.11 & 1.07 & 1.02 & 1.13 & 1.06 & 1.02 & 1.05 & 1.07 & 1.07 \\
\hline & D5 & 1.07 & 1.07 & 1.11 & 0.92 & 1.07 & 1.11 & 1.08 & 0.99 & 0.93 & 1.09 & 1.04 \\
\hline & Mean & 1.17 & 1.19 & 1.20 & 1.05 & 1.13 & 1.21 & 1.15 & 1.07 & 1.05 & 1.21 & 1.14 \\
\hline & LSD 5\%,1\% for: & & & & & & & & & & & \\
\hline & Sowing date(D) & \multicolumn{11}{|c|}{$0.05,0.08$} \\
\hline & Genotype (G) & \multicolumn{11}{|c|}{$0.04,0.05$} \\
\hline \multirow{9}{*}{$\begin{array}{c}2018-2020 \\
\text { (Exp. II). }\end{array}$} & D1 & 1.02 & 1.02 & 1.13 & 0.93 & 1.03 & 1.06 & 1.04 & 0.90 & 0.92 & 1.06 & 1.01 \\
\hline & $\mathrm{D} 2$ & 1.05 & 1.07 & 1.18 & 0.90 & 1.10 & 1.15 & 1.16 & 1.01 & 1.02 & 1.27 & 1.09 \\
\hline & D3 & 1.17 & 1.19 & 1.19 & 1.03 & 1.12 & 1.20 & 1.10 & 1.11 & 1.07 & 1.27 & 1.14 \\
\hline & D4 & 1.09 & 1.09 & 1.12 & 0.93 & 1.01 & 1.07 & 1.07 & 1.02 & 0.96 & 1.12 & 1.05 \\
\hline & D5 & 1.27 & 1.32 & 1.28 & 1.11 & 1.24 & 1.53 & 1.28 & 1.22 & 1.09 & 1.38 & 1.27 \\
\hline & Mean & 1.12 & 1.14 & 1.18 & 0.98 & 1.10 & 1.20 & 1.13 & 1.05 & 1.01 & 1.22 & 1.11 \\
\hline & LSD $5 \%, 1 \%$ for: & & & & & & & & & & & \\
\hline & Sowing date(D) & & & & & & & & & \multicolumn{3}{|c|}{$0.10,0.14$} \\
\hline & Genotype (G) & & & & & & & & & \multicolumn{3}{|c|}{$0.07,0.10$} \\
\hline
\end{tabular}

D1 $=10^{\text {th }}$ October, D2 $=10^{\text {th }}$ November, D3 $=10^{\text {th }}$ December, D4 $=20^{\text {th }}$ March, D5 $=20^{\text {th }}$ April, D1, D2 and D3 autumn sowing dates, D4 and D5 spring sowing dates. 
The average leaves/stems ratio as affected by sowing dates and genotypes in Experiment-I (2017 to 2019) and Experiment-II (2018 to 2020) are presented in Table 5. Comparisons among the five planting dates showed that sowing at November $10^{\text {th }}$ (D2) and December $10^{\text {th }}$ (D3) gave the highest mean values of leaves/stems ratio which were 1.23 in both planting dates for experiment-I. But in experiment II sowing at April $20^{\text {th }}$ (D5) gave the highest mean values of leaves/stems ratio which were 1.27. Moreover, the results indicated that leaves/stems ratio reduced to the minimum value at the fifth (D5) and fourth (D4) sowing dates in experiment I and II, respectively. This may be due to the large differences in climatic conditions prevailing in five sowing dates during growing years.

These results are in line with that reported by Abd El-Rady (2018) who found that sowing at November $20^{\text {th }}$ gave the highest mean values of leaves/stems ratio.

Comparing between the average leaves/stems ratio of the different genotypes over all five sowing dates concluded that Cuf 101 genotype produced the highest leaves/stems ratio $(1.21 \& 1.22 \%)$ as compared with the other tested genotypes in both experiments. On the other hand, Ramah-1 genotype produced the lowest leaves/stems ratio of 1.05 and $0.98 \%$ in experiments I and II, respectively.

Moreover, Cuf 101 genotype gave the highest leaves/stems ratio of 1.32 which was obtained when sowing was performed on November $10^{\text {th }}$ (D2) in experiment I and 1.38 was obtained when sowing was performed on April $10^{\text {th }}$ (D5) in experiment II (Table 5). This may be due to the differences in climatic conditions prevailing in five sowing dates during growing years. These results confirm the genetic variation reported by Abd El-Halim et al. (1992), Abdel-Galil \& Hamed (2008), Hamd Alla (2012) and Abd El-Rady (2018).

\section{A.3- Total fresh forage yield $\left(\mathrm{kg} / \mathrm{m}^{2}\right)$ :}

The analysis of variance of this trait in both experiments I (20172019) and II (2018-2020) is given in Table 3 . The mean squares revealed highly significant differences among sowing dates in both experiments. Also, the genotypes were highly significant in both experiments. Meanwhile, the interaction between sowing dates $\mathrm{x}$ genotypes were insignificant in both experiments. One of the reason of this insignificant may be due to the estimated of plant height was from average of fifteen cuts.

Total fresh forage yield $\left(\mathrm{kg} / \mathrm{m}^{2}\right)$ as influenced by sowing dates and genotypes in two experiments and are presented in Table 6 . The results revealed that the maximum total fresh forage yield $\left(\mathrm{kg} / \mathrm{m}^{2}\right)$ of $44.62 \mathrm{ob}$ tained from sowing at March $20^{\text {th }}$ (D4) in experiment I and $58.56 \mathrm{~kg} / \mathrm{m}^{2}$ from sowing on October $10^{\text {th }}$ (D1) in experiment II.

This result may be due to the different between the two experiments for climatic conditions (Tables 3,4 and 5). These results are in agreement with those obtained by Hamd Alla (2012) and Abd El-Rady (2018).

The results also showed lowest total forage yield $\left(\mathrm{kg} / \mathrm{m}^{2}\right)$ which were obtained from sowing on April $20^{\text {th }}$ 
(D5) in both experiments. Also, these results are in agreement with those obtained by Mueller (2005) who found that temperature and photoperiod influence alfalfa seedling development.

Concerning the effect of genotypes on the total fresh forage yield, Ramah-1 genotype produced the highest fresh forage yield of 36.81 and $52.22 \mathrm{~kg} / \mathrm{m}^{2}$ in experiment I and II respectively. In general, all most the studied genotypes had the highest total fresh forage yield when they were sown on October $10^{\text {th }}$ (D1) as revealed in both experiments.

The second growing years (experiment II) gave higher values than the first one for total fresh forage yield. This may be due to the differences in climatic conditions prevailing in five sowing dates during growing years.
These results confirm the genetic variation within and among the studied genotypes. These results are in agreement with those reported by Abd El-Halim et al. (1992), AbdelGalil \& Hamed (2008) and Abd ElRady (2018).

The results in Table 6 showed that Ramah-1 genotype was the best (47.36) in the fourth (D4) date of the first experiment and $(65.62) \mathrm{kg} / \mathrm{m}^{2}$ in the first (D1) date of the second experiment.

Concerning to the best genotype Ramah-1 in total fresh forage yield, it is to be logic since under overall sowing dates produced the highest mean value of plant height and consequently produced the highest fresh forage yield.

Table 6. Total fresh forage yield $\left(\mathrm{kg} / \mathrm{m}^{2}\right)$ of the ten alfalfa genotypes under each sowing dates in 2017-2019 (Exp. I) and 2018-2020 (Exp. II).

\begin{tabular}{|c|c|c|c|c|c|c|c|c|c|c|c|c|}
\hline \multirow[b]{2}{*}{ Years } & \multirow[b]{2}{*}{ Sowing date } & \multicolumn{11}{|c|}{ Genotypes } \\
\hline & & 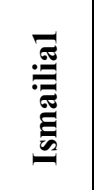 & 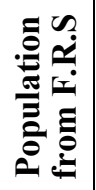 &  & 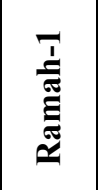 & 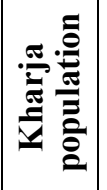 & 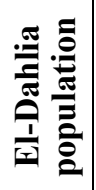 & 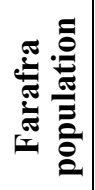 & 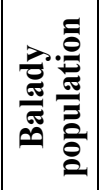 & 焉 & $\underset{\Xi}{\Xi}$ & Mean \\
\hline \multirow{9}{*}{$\begin{array}{c}2017-2019 \\
\text { (Exp. I) }\end{array}$} & D1 & 39.10 & 34.31 & 41.55 & 45.51 & 41.61 & 38.61 & 41.57 & 41.59 & 41.69 & 38.78 & 40.43 \\
\hline & D2 & 24.54 & 23.69 & 23.00 & 24.22 & 22.91 & 26.88 & 26.74 & 26.58 & 26.41 & 25.25 & 25.02 \\
\hline & D3 & 38.16 & 34.48 & 39.34 & 41.90 & 34.73 & 36.05 & 34.53 & 38.54 & 39.20 & 36.34 & 37.33 \\
\hline & D4 & 42.78 & 40.19 & 47.35 & 47.36 & 42.87 & 42.88 & 45.51 & 45.05 & 46.32 & 45.93 & 44.62 \\
\hline & D5 & 24.73 & 22.90 & 25.10 & 25.07 & 24.32 & 24.26 & 24.44 & 25.27 & 24.03 & 24.36 & 24.45 \\
\hline & Mean & 33.86 & 31.11 & 35.26 & 36.81 & 33.29 & 33.73 & 34.56 & 35.40 & 35.53 & 34.13 & 34.37 \\
\hline & LSD 5\%,1\% for: & & & & & & & & & & & \\
\hline & Sowing date(D) & & & & & & & & & & $1.44,2$. & .09 \\
\hline & Genotype (G) & & & & & & & & & & $1.69,2$. & 32 \\
\hline \multirow{9}{*}{$\begin{array}{l}2018-2020 \\
\text { (Exp. II). }\end{array}$} & D1 & 51.74 & 56.42 & 54.83 & 65.62 & 56.12 & 57.65 & 55.56 & 63.58 & 65.23 & 58.82 & 58.56 \\
\hline & D2 & 51.34 & 46.67 & 44.59 & 49.13 & 45.09 & 46.79 & 46.31 & 48.83 & 49.28 & 43.59 & 47.16 \\
\hline & D3 & 42.80 & 44.38 & 46.52 & 47.80 & 43.73 & 46.12 & 47.51 & 54.14 & 46.55 & 47.58 & 46.71 \\
\hline & D4 & 44.13 & 42.28 & 45.29 & 52.11 & 46.95 & 48.51 & 46.25 & 47.96 & 49.80 & 45.36 & 46.86 \\
\hline & D5 & 42.71 & 45.12 & 43.96 & 46.42 & 44.93 & 47.75 & 47.04 & 45.24 & 47.70 & 44.86 & 45.57 \\
\hline & Mean & 46.54 & \begin{tabular}{|l|}
46.97 \\
\end{tabular} & 47.04 & 52.22 & 47.36 & 49.36 & 48.53 & 51.95 & 51.71 & 48.04 & 48.97 \\
\hline & LSD 5\%,1\% for: & & & & & & & & & & & \\
\hline & Sowing date(D) & \multicolumn{11}{|c|}{$4.34,6.31$} \\
\hline & Genotype (G) & \multicolumn{11}{|c|}{$2.00,2.74$} \\
\hline
\end{tabular}




\section{A.4- Total dry forage yield $\left(\mathrm{Kg} / \mathrm{m}^{2}\right)$ :}

The analyses of variance of this trait in experiments I (2017-2019) and II (2018-2020) are presented in Table 3. The mean squares for total dry forage yield revealed that highly significant differences among the five sowing dates in both experiments. Also, the mean squares for this trait revealed that the highly significant differences among the ten alfalfa genotypes in both experiments.

Meanwhile, the interaction between sowing dates $x$ genotypes were insignificant in both experiments. The reason of this insignificant may be due to the estimated of total dry forage yield from the total fifteen cuts.

The variance of total dry forage yield between two experiments was detected and not homogeneity, consequently the combined analysis was not done.

Total dry forage yield $\left(\mathrm{Kg} / \mathrm{m}^{2}\right)$ as influenced by sowing dates and genotypes in two experiments are presented in Table 7 . The results in Table 7 revealed that the maximum total dry forage yield of $9.70 \mathrm{~kg} / \mathrm{m}^{2}$ was obtained from sowing at March $20^{\text {th }}$ (D4) in experiment I and 12.24 $\mathrm{kg} / \mathrm{m}^{2}$ at October $10^{\text {th }}$ (D1) in experiment II. These results are in line with this reported by Cakmakci et al. (2004) in Turkey and Abd-El-Rady (2018) in Egypt, who found that the best sowing date of alfalfa was the last week of October. This may be due to the different between two experiments for climatic conditions (Table 1). These results are in agreement with obtained many authors i.e. Hamd Alla (2012) and Abd El-Rady (2018).

The results also showed that the lowest total dry forage yield $\left(\mathrm{kg} / \mathrm{m}^{2}\right)$ were obtained from sowing on April $20^{\text {th }}$ in both experiments. These results are in agreement with those obtained by Mueller (2005) who found that temperature and photoperiod influence alfalfa seedling development.

On the other hand, in experiment I significant differences were noticed in total dry forage yield among the most five sowing dates. While, in experiment II, no significant differences were noticed in total dry forage yield among all sowing dates except sowing date at October $10^{\text {th }}$.

Concerning the effect of genotypes on the total dry forage yield, Ramah-1 genotype produced the highest total dry forage yield of 8.21 and $10.92 \mathrm{~kg} / \mathrm{m}^{2}$ in experiments I and II, respectively. This is to be logic since the same trend was observed regarding fresh forage yields. In general, all most the studied genotypes had the highest total dry forage yield when they were sown on March $20^{\text {th }}$ (D4) in experiment I while of October $10^{\text {th }}$ (D1) in experiment II. 
Table 7. Total dry forage yield $\left(\mathrm{Kg} / \mathrm{m}^{2}\right)$ : for fifteen cuts of the ten alfalfa genotypes under each sowing dates in 2017-2019 (Exp. I) and 2018-2020 (Exp. II).

\begin{tabular}{|c|c|c|c|c|c|c|c|c|c|c|c|c|}
\hline \multirow[b]{2}{*}{ Years } & \multirow[b]{2}{*}{ Sowing date } & \multicolumn{11}{|c|}{ Genotypes } \\
\hline & & 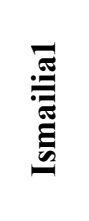 & 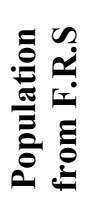 & 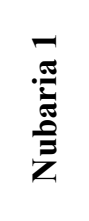 & 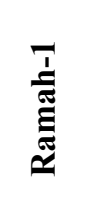 & 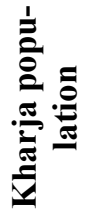 &  & 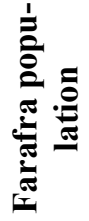 & 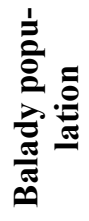 & 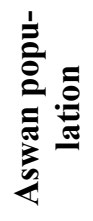 & $\begin{array}{l}\bar{\Xi} \\
\\
\Xi\end{array}$ & Mean \\
\hline \multirow{9}{*}{$\mid \begin{array}{c}\text { 2017-2019 } \\
\text { (Exp. I) }\end{array}$} & D1 & 8.43 & 7.90 & 9.47 & 10.18 & 9.44 & 8.94 & 9.29 & 9.45 & 9.34 & 8.81 & 9.13 \\
\hline & $\mathrm{D} 2$ & 5.42 & 5.35 & 5.07 & 5.38 & 5.19 & 6.04 & 5.83 & 5.75 & 5.85 & 5.58 & 5.55 \\
\hline & D3 & 8.42 & 7.70 & 8.68 & 9.56 & 7.99 & 8.11 & 7.90 & 8.56 & 8.70 & 7.83 & 8.34 \\
\hline & D4 & 9.16 & 8.77 & 10.42 & 10.25 & 9.46 & 9.45 & 9.96 & 9.73 & 10.05 & 9.72 & 9.70 \\
\hline & D5 & 5.64 & 5.04 & 5.66 & 5.68 & 5.68 & 5.65 & 5.55 & 5.65 & 5.43 & 5.33 & 5.53 \\
\hline & Mean & 7.41 & 6.95 & 7.86 & 8.21 & 7.55 & 7.64 & 7.71 & 7.83 & 7.87 & 7.45 & 7.65 \\
\hline & LSD $5 \%, 1 \%$ for: & & & & & & & & & & & \\
\hline & Sowing da & \multicolumn{11}{|c|}{$0.28,0.41$} \\
\hline & Genotype (G) & \multicolumn{11}{|c|}{$0.39,0.54$} \\
\hline \multirow{9}{*}{$\begin{array}{c}2018-2020 \\
\text { (Exp. II). }\end{array}$} & D1 & 10.80 & 11.93 & 11.14 & 13.86 & 12.12 & 12.33 & 11.89 & 12.89 & 13.60 & 11.87 & 12.24 \\
\hline & D2 & 10.36 & 9.66 & 9.30 & 9.94 & 9.12 & 9.39 & 9.61 & 10.08 & 9.87 & 8.64 & 9.60 \\
\hline & D3 & 8.80 & 9.21 & 9.26 & 10.28 & 9.07 & 9.71 & 9.90 & 11.46 & 9.70 & 9.23 & 9.66 \\
\hline & D4 & 9.30 & 9.03 & 9.23 & 10.84 & 9.50 & 10.20 & 9.50 & 9.87 & 10.36 & 9.10 & \begin{tabular}{|l|}
9.69 \\
\end{tabular} \\
\hline & D5 & 9.05 & 9.58 & 9.16 & 9.67 & 9.38 & 10.47 & 10.05 & 9.45 & 10.04 & 8.98 & \begin{tabular}{|c|}
9.58 \\
\end{tabular} \\
\hline & Mean & 9.66 & 9.88 & 9.62 & 10.92 & 9.84 & 10.42 & 10.19 & 10.75 & 10.71 & 9.56 & 10.16 \\
\hline & LSD $5 \%, 1 \%$ for: & & & & & & & & & & & \\
\hline & Sowing date(D) & & & & & & & & & & & $0,1.45$ \\
\hline & Genotype (G) & & & & & & & & & & & $40,0.55$ \\
\hline
\end{tabular}

D1 $=10^{\text {th }}$ October, D2 $=10^{\text {th }}$ November, $\mathbf{D 3}=10^{\text {th }}$ December, D4 $=20^{\text {th }}$ March, D5 $=20^{\text {th }}$ April, D1, D2 and D3 autumn sowing dates, D4 and D5 spring sowing dates.

These results confirm the genetic variation within and among the studied genotypes. These results are in agreement with those reported by Abd El-Halim et al. (1992), AbdelGalil \& Hamed (2008) and Abd ElRady (2018).

The results in Table 7 showed that Ramah-1 genotype was the best $\left(10.25 \mathrm{~kg} / \mathrm{m}^{2}\right)$ in the fourth date (D4) of the first experiment, while the same genotype (Ramah-1) was the best $\left(13.86 \mathrm{~kg} / \mathrm{m}^{2}\right)$ in the first date (D1) of the second experiment. This is to be logic since under overall sowing dates produced the highest mean value of plant height, consequently produced the highest fresh forage yield and Seasonal dry forage yield. Otherwise, population from F.RS genotype produced the lowest value of $6.95 \mathrm{~kg} / \mathrm{m}^{2}$ in experiment I, as well as Cuf101 genotype produced the lowest one of $9.56 \mathrm{Kg} / \mathrm{m}^{2}$ in experiment II over all sowing dates.

These results are in line with those reported by Abd El-Halim et al. (1992 and 1998), Mouse et al. (1996), Geweifel (1997), Oushy et al. (2007), Abdel- Galil \& Hamed (2008), Hamad Allah et al. (2013), Ibrahim et al. (2014) and Abd El-Rady et al. (2018), who reported that significant differences were noticed in total dry forage yield among alfalfa genotypes.

\section{A.5- Total Protein forage yield} $\left(\mathrm{Kg} / \mathrm{m}^{2}\right)$ :

The analyses of variance of total protein forage yield in experiments I (2017-2019) and II (2018-2020) are presented in Table 3. 
Mean squares for this trait revealed highly significant differences among the five sowing dates in both experiments I and II as well as among the genotypes in experiment II. While, the mean squares for this trait revealed insignificant differences among the ten studied alfalfa genotypes in experiments I. The interaction between sowing dates $\mathrm{x}$ genotypes was insignificant in both ex- periments, this may be due to the estimated of total protein forage yield was from the total of fifteen cuts. Also, this may be due to the different between the two experiments for climatic conditions (Table 1).

The variance of total protein yield between two experiments was detected and not homogeneity, consequently the combined analysis was not done.

Table 8. Total Protein forage yield $\left(\mathrm{Kg} / \mathrm{m}^{2}\right)$ : for fifteen cuts of the ten alfalfa genotypes under each sowing dates in 2017-2019 (Exp. I) and 2018-2020 (Exp. II).

\begin{tabular}{|c|c|c|c|c|c|c|c|c|c|c|c|c|}
\hline \multirow[b]{2}{*}{ Years } & \multirow[b]{2}{*}{ Sowing date } & \multicolumn{11}{|c|}{ Genotypes } \\
\hline & & 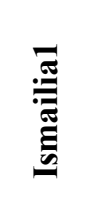 & 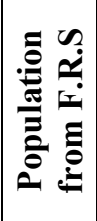 & 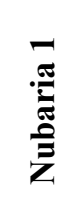 & 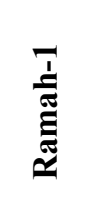 & 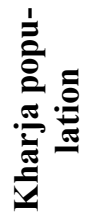 & 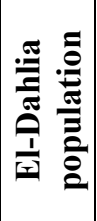 & 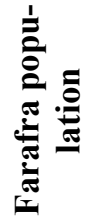 & 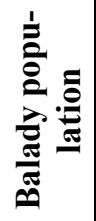 & 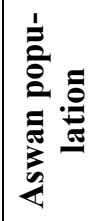 & $\begin{array}{l}\bar{\theta} \\
\bar{E}\end{array}$ & Mean \\
\hline \multirow{9}{*}{$\begin{array}{c}2017-2019 \\
\text { (Exp. I) }\end{array}$} & D1 & 1.86 & 1.56 & 1.95 & 2.16 & 2.27 & 2.10 & 1.89 & 2.01 & 1.85 & 1.88 & 1.95 \\
\hline & D2 & 1.27 & 1.10 & 1.17 & 1.09 & 1.15 & 1.24 & 1.23 & 1.25 & 1.27 & 1.19 & 1.20 \\
\hline & D3 & 2.01 & 1.53 & 1.93 & 1.91 & 1.74 & 1.77 & 1.69 & 1.86 & 1.99 & 1.74 & 1.82 \\
\hline & D4 & 2.02 & 1.80 & 2.19 & 2.23 & 2.19 & 1.96 & 2.32 & 2.13 & 2.00 & 2.12 & 2.10 \\
\hline & D5 & 1.29 & \begin{tabular}{|l|}
1.07 \\
\end{tabular} & 1.26 & 1.28 & 1.30 & 1.19 & 1.18 & 1.21 & 1.27 & 1.20 & 1.22 \\
\hline & Mean & 1.69 & \begin{tabular}{|l|}
1.41 \\
\end{tabular} & 1.70 & 1.73 & 1.73 & 1.65 & 1.66 & 1.69 & 1.68 & 1.63 & 1.66 \\
\hline & LSD 5\%,1\% for: & \multirow{2}{*}{\multicolumn{11}{|c|}{$0.09,0.13$}} \\
\hline & Sowing date(D) & & & & & & & & & & & \\
\hline & Genotype (G) & \multicolumn{11}{|c|}{$0.10,0.13$} \\
\hline \multirow{9}{*}{$\begin{array}{l}\text { 2018-2020 } \\
\text { (Exp. II). }\end{array}$} & D1 & 2.56 & 2.73 & 2.46 & 2.99 & 2.46 & 2.63 & 2.60 & 2.56 & 2.88 & 2.66 & 2.65 \\
\hline & $\mathrm{D} 2$ & 1.94 & 1.92 & 1.82 & 2.18 & 1.82 & 1.81 & 2.06 & 2.00 & 1.92 & 1.91 & 1.94 \\
\hline & D3 & 1.76 & 1.81 & 1.79 & 2.17 & 1.94 & 2.09 & 2.00 & 2.26 & 1.86 & 1.77 & 1.95 \\
\hline & $\mathrm{D} 4$ & 1.61 & 1.74 & 1.75 & 2.30 & 1.87 & 1.71 & 1.67 & 1.75 & 1.87 & 1.60 & 1.79 \\
\hline & D5 & 1.71 & 1.67 & 1.80 & 1.71 & 2.00 & 2.18 & 1.98 & 1.83 & 1.74 & 1.65 & 1.83 \\
\hline & Mean & 1.92 & \begin{tabular}{|l|}
1.97 \\
\end{tabular} & 1.92 & 2.27 & 2.02 & 2.08 & 2.06 & 2.08 & 2.06 & 1.92 & 2.03 \\
\hline & LSD 5\%,1\% for: & & & & & & & & & & & \\
\hline & Sowing date(D) & \multicolumn{11}{|c|}{$0.16,0.23$} \\
\hline & Genotype (G) & & & & & & & & & & \multicolumn{2}{|c|}{$0.11,0.15$} \\
\hline
\end{tabular}

The average of total protein forage yield as influenced by the five sowing dates and ten alfalfa genotypes in experiment I (2017-2019) and experiment II (2018-2020) are shown in Table 8.

The results showed that the total protein forage yield varied from 1.20 $\mathrm{kg} / \mathrm{m}^{2}$ for sowing date at November $10^{\text {th }}$ (D2) to $2.10 \mathrm{~kg} / \mathrm{m}^{2}$ for sowing date at March $20^{\text {th }}$ (D4) in experiment I. Moreover, the total protein forage yield varied from $1.79 \mathrm{~kg} / \mathrm{m}^{2}$ for sowing date at March $20^{\text {th }}$ (D4) to 2.65 $\mathrm{kg} / \mathrm{m}^{2}$ for sowing date at October $10^{\text {th }}$ (D1) in experiment II, with as average of 1.66 and $2.03 \mathrm{~kg} / \mathrm{m}^{2}$ over all sowing date in the experiment I and 
II, respectively. Also, this trait varied for $1.41 \mathrm{~kg} / \mathrm{m}^{2}$ for population F.R.S to $1.73 \mathrm{~kg} / \mathrm{m}^{2}$ for Ramah-1 genotype in experiment I. While, this trait varied from $1.92 \mathrm{~kg} / \mathrm{m}^{2}$ for Ismailia-1, Nubaria-1, and Cuf101 genotypes to $2.27 \mathrm{~kg} / \mathrm{m}^{2}$ for Ramah-1 genotypes in experiment II.

Concerning the effect of genotypes on the total protein forage yield, Ramah-1 genotype produced the highest total protein forage yield of 1.73 and $2.27 \mathrm{~kg} / \mathrm{m}^{2}$ in experiment I and II, respectively. While, Cuf101 genotypes produced the lowest total protein forage yield of 1.63 and 1.92 $\mathrm{kg} / \mathrm{m}^{2}$ in the same manner.

Comparison between the total protein forage yield of five sowing date and varieties, it be concluded that Ramah-1 genotype produced approximately the highest total protein forage yield of $2.23 \mathrm{~kg} / \mathrm{m}^{2}$ at March, $20^{\text {th }}$ sowing date in experiment I, but was $2.99 \mathrm{~kg} / \mathrm{m}^{2}$ at October $10^{\text {th }}$ sowing date in experiment II.

This is to be logic since the same sowing date produced the highest mean plant height, fresh and dry forage yield.

These results are in line with those obtained Hand Allah (2012) and Abd El-Rady (2018).

\section{B- Simple correlation coefficient analysis}

Simple correlation coefficients for forage yield and its components in experiments I and II in each and over sowing date could be exerted in Tables $9 \mathrm{a}, \mathrm{b}, \mathrm{c}, \mathrm{d}$, e.

In general, the correlation coefficients between each pairs of the forage trait and its components for each and over sowing date and experi- ments showed different degree of relationships among these traits.

In general, protein forage yield $/ \mathrm{m}^{2}$ was different correlated with each of plant height, fresh forage yield, dry forage yield, leaves/stem ratio, protein percentage and dry matter percentage from sowing date to another and from experiment I to experiment II. For example, the correlated values between the total protein forage yield and each of previous traits in first sowing date (D1) were $\mathrm{r}=0.329, \quad 0.701 *, \quad 0.749, \quad-0.237$, $0.741^{*}$ and -0.033 in experiment I and $0.639^{*}, 0.721^{*}, 0.764^{*},-0.593$, 0.095 and 0.103 in experiment II, respectively (Table 9a). While, these values of correlations among the same traits in second sowing date (D2) were $-0.138,0.693 *, 0.635^{*}$, $0.121,0.407$ and -0.537 in experiment I and $0.616,0.449,0.480$, $0.594,0.590$ and 0.060 in experiment II, respectively (Table 9b).

The values of correlations in the same order in third sowing date (D3) were $0.483,0.801 * *, 0.733 *,-0.509$, $0.649^{*}$ and -0.217 in experiment I and $0.614,0.693^{*}, 0.875^{* *},-0.559$, 0.521 and $0.760^{*}$ in experiment II, respectively (Table 9c).

The view of correlations in forth sowing date (D4), among the same traits were $0.135,0.693^{*}, 0.717^{*}$, $0.251,0.719^{*}$ and 0.050 in experiment I and $0.933^{* *}, 0.746^{*}, 0.758^{*}$, $0.836^{* *}, 0.846^{* *}$ and 0.058 in experiment II, respectively (Table 9d).

Furthermore, in fifth sowing date (D5), these correlations between the same traits were $0.146,0.658^{*}$, $0.764 *,-0.319,0.778 * *$ and 0.503 in experiment I and $-0.127,0.459$, $0.637^{*}, 0.481,0.835^{* *}$ and $0.644^{*}$ in 
experiment II, respectively (Table 9e).

These results may be due to the different of climatic conditions i.e. temperature, relative humidity, and sun shine (Table 1).

The simple correlations among studied traits over all the five sowing dates for each experiment are shown in Table 9f.

In general, protein forage yield $/ \mathrm{m}^{2}$ was positively correlated with each of plant height, fresh forage yield, dry forage yield and protein percentage in each experiment, i.e.,
$0.101,0.971^{* *}, 0.974 *$ and 0.109 in experiment I and 0.290*, 0.895*, $0.911^{*}$ and $0.759^{*}$ in experiment II, respectively). While protein forage yield was negatively correlated with leaves/stems ratio of -0.129 in experiment I and $-0.451^{* *}$ in experiment II). Leaves/ stems ratio was negatively correlated with each of plant height, fresh forage yield, dry forage yield and protein percentage i.e. $-0.903^{* *},-0.144,-0.132$ and 0.021 in experiment I and $-0.831^{* *}$, $0.570^{* *},-0.531^{* *}$ and -0.158 in experiment II.

Table 9. Correlations among forage yield and their components for each and over sowing date in experiments I (above) and II( below). a- First sowing date (D1).

\begin{tabular}{|c|c|c|c|c|c|c|c|}
\hline & PH & FFY & DFY & PY & LS & PDM & PP \\
\hline PH & & $0.785^{* *}$ & $0.689^{*}$ & 0.329 & $-0.693^{*}$ & -0.474 & -0.208 \\
\hline FFY & $0.773^{* *}$ & & $0.965^{* *}$ & $0.701^{*}$ & $-0.704^{*}$ & -0.311 & 0.082 \\
\hline DFY & $0.825^{* *}$ & $0.954^{* *}$ & & $0.749^{*}$ & $-0.635^{*}$ & -0.052 & 0.111 \\
\hline PY & $0.639^{*}$ & $0.721^{*}$ & $0.764^{*}$ & & -0.237 & 0.033 & $0.741^{*}$ \\
\hline LS & $-0.895^{* *}$ & $-0.786^{* *}$ & $-0.784^{* *}$ & -0.593 & & 0.359 & 0.285 \\
\hline PDM & 0.149 & -0.179 & 0.122 & 0.103 & 0.018 & & 0.073 \\
\hline PP & -0.437 & -0.550 & -0.568 & 0.095 & 0.424 & -.063 & \\
\hline
\end{tabular}

b- Second sowing date (D2).

\begin{tabular}{|c|c|c|c|c|c|c|c|}
\hline & PH & FFY & DFY & PY & LS & PDM & PP \\
\hline PH & & 0.189 & 0.200 & -0.138 & $-0.883^{* *}$ & 0.020 & -0.420 \\
\hline FFY & $0.758^{*}$ & & $0.974^{* *}$ & $0.693^{*}$ & -0.353 & -0.491 & -0.362 \\
\hline DFY & $0.670^{* *}$ & $0.946^{* *}$ & & $0.635^{*}$ & -0.316 & -0.282 & -0.444 \\
\hline PY & 0.616 & 0.449 & 0.480 & & -0.121 & -0.537 & 0.407 \\
\hline LS & $-0.872^{* *}$ & $-0.781^{* *}$ & $-0.780^{* *}$ & -0.594 & & 0.225 & 0.270 \\
\hline PDM & -0.270 & -0.126 & 0.201 & 0.060 & $\overline{0.002}$ & $\overline{-}$ & -0.223 \\
\hline PP & 0.011 & -0.396 & -0.421 & 0.590 & 0.136 & -0.143 & \\
\hline
\end{tabular}

Where $\mathrm{PH}=$ Plant height; FFY = Fresh forage yield; DFY= Dry forage yield; $\mathrm{PY}=$ Protein forage yield; $\mathrm{LS}=$ Leaves/stem ratio; $\mathrm{DMP}=$ Dry matter percentage; $\mathrm{PP}=$ Protein percentage.

$*, * *$ significant at 0.05 and 0.01 levels of probability, respectively.

c- Third sowing date (D3).

\begin{tabular}{|c|c|c|c|c|c|c|c|}
\hline & PH & FFY & DFY & PY & LS & PDM & PP \\
\hline PH & & 0.621 & $0.679^{*}$ & 0.485 & $-0.817^{* *}$ & 0.213 & -0.055 \\
\hline FFY & 0.292 & & $0.957^{* *}$ & $0.801^{* *}$ & -0.627 & -0.153 & 0.102 \\
\hline DFY & 0.533 & $0.929^{* *}$ & & $0.733^{*}$ & $-0.724^{* *}$ & 0.140 & -0.038 \\
\hline PY & 0.614 & $0.693^{*}$ & $0.875^{* *}$ & & -0.509 & -0.217 & $0.649^{*}$ \\
\hline LS & $-0.833^{* *}$ & -0.234 & -0.493 & -0.559 & & -0.354 & 0.058 \\
\hline PDM & $0.751^{*}$ & 0.208 & 0.555 & $0.760^{*}$ & $-0.777^{* *}$ & & -0.456 \\
\hline PP & 0.322 & -0.204 & 0.044 & 0.521 & -0.286 & 0.586 & \\
\hline
\end{tabular}


Table 9. Continued.

d- Fourth sowing date (D4).

\begin{tabular}{|c|c|c|c|c|c|c|c|}
\hline & PH & FFY & DFY & PY & LS & PDM & PP \\
\hline PH & & 0.195 & 0.212 & 0.135 & -0.585 & 0.084 & 0.003 \\
\hline FFY & $0.786^{* *}$ & & $0.967^{* *}$ & $0.693^{*}$ & 0.013 & -0.168 & 0.037 \\
\hline DFY & $0.775^{* *}$ & $0.954^{* *}$ & & $0.717^{*}$ & 0.059 & 0.088 & 0.033 \\
\hline PY & $0.933^{* *}$ & $0.746^{*}$ & $0.758^{*}$ & & -0.251 & 0.050 & $0.719^{*}$ \\
\hline LS & $-0.924^{* *}$ & $-0.839^{* *}$ & $-0.855^{* *}$ & $-0.836^{* *}$ & $\overline{ }$ & 0.161 & -0.426 \\
\hline PDM & -0.021 & -0.146 & 0.157 & 0.058 & -0.063 & $\overline{1}$ & -0.039 \\
\hline PP & $0.740^{*}$ & 0.315 & 0.298 & $0.846^{* *}$ & -0.544 & -0.035 & \\
\hline
\end{tabular}

Where $\mathrm{PH}=$ Plant height; FFY= Fresh forage yield; DFY= Dry forage yield; PY= Protein forage yield; $\mathrm{LS}=$ Leaves/stem ratio; $\mathrm{DMP}=$ Dry matter percentage; $\mathrm{PP}=$ Protein percentage.

*,** significant at 0.05 and 0.01 levels of probability, respectively.

e- Fifth sowing date (D5).

\begin{tabular}{|c|c|c|c|c|c|c|c|}
\hline & PH & FFY & DFY & PY & LS & PDM & PP \\
\hline PH & & 0.117 & 0.083 & 0.146 & $-0.889^{* *}$ & -0.016 & 0.125 \\
\hline FFY & 0.485 & & $0.843^{* *}$ & $0.658^{*}$ & -0.192 & 0.179 & 0.187 \\
\hline DFY & 0.492 & $0.908^{* *}$ & & $0.764^{*}$ & -0.087 & $0.679^{*}$ & 0.195 \\
\hline PY & -0.127 & 0.459 & $0.637^{*}$ & & -0.319 & 0.503 & $0.778^{* *}$ \\
\hline LS & -0.613 & -0.010 & 0.147 & 0.481 & & 0.107 & -0.415 \\
\hline PDM & 0.321 & 0.389 & $0.739^{*}$ & $0.644^{*}$ & 0.329 & & 0.107 \\
\hline PP & -0.511 & -0.047 & 0.111 & $0.835^{* *}$ & 0.482 & 0.297 & \\
\hline
\end{tabular}

f: Continued (overall sowing dates).

\begin{tabular}{|c|c|c|c|c|c|c|c|}
\hline & PH & FFY & DFY & PY & LS & DMP & PP \\
\hline PH & & 0.122 & 0.108 & 0.101 & $-0.903^{* *}$ & -0.084 & -0.013 \\
\hline FFY & $0.418^{* *}$ & & $0.996^{* *}$ & $0.971^{* *}$ & -0.144 & $-0.326^{*}$ & -0.106 \\
\hline DFY & $0.393^{* *}$ & $0.979^{* *}$ & & $0.974^{* *}$ & -0.132 & -0.237 & -0.114 \\
\hline PY & $0.290^{*}$ & $0.895^{* *}$ & $0.911^{* *}$ & & -0.129 & -0.249 & 0.109 \\
\hline LS & $-0.831^{* *}$ & $-0.570^{* *}$ & $-0.531^{* *}$ & $-0.451^{* *}$ & & 0.081 & -0.021 \\
\hline PDM & -0.035 & 0.118 & $0.316^{*}$ & 0.269 & 0.069 & & -0.048 \\
\hline PP & 0.032 & $0.421^{* *}$ & $0.424^{* *}$ & $0.759^{* *}$ & -0.158 & $\overline{0.095}$ & \\
\hline
\end{tabular}

Where $\mathrm{PH}=$ Plant height; FFY= Fresh forage yield; DFY= Dry forage yield; $\mathrm{PY}=$ Protein forage yield; $\mathrm{LS}=$ Leaves/stem ratio; $\mathrm{DMP}=$ Dry matter percentage; $\mathrm{PP}=$ Protein percentage.

*,** significant at 0.05 and 0.01 levels of probability, respectively.

These results indicated that the most effective components in protein forage yield of alfalfa would be fresh and dry forage yield in major issue in both experiment, while the plant height and protein percentage in minor role in experiment II only were the values of correlation were positive and significant. It is remark results that the last conclusion over all sowing dates could be extent to the late sowing date i.e. fourth and fifth sowing dates (Tables $9 \mathrm{~d}, \mathrm{e}, \mathrm{f}$ ).

Sengul (2002) considered the plant height and stem yield as the forage yield components. Also, these traits are the most frequently used as selection criteria in alfalfa breeding programs (Popovic, 2006). Tuckak et al. (2008) reported that plant height is an important yield component and it is often used as a criterion when 
choosing superior genotypes in an early stage of selection. The results of this research are consistent with the results of other researchers (Julier et al., 2000; Pupovic, 2006 and Abd ElRady, 2018).

Abd El-Rady (2018) reported that protein forage yield was positively correlated with each of plant height, fresh forage yield, dry matter and protein percentage in each sowing dates. But the plant height was negatively correlated with each of leaves/stems ratio and dry matter percentage in each sowing date. Leaves/stems ratio was negatively correlated with fresh forage yield.

\section{References}

A.O.A.C. (1980). Official Methods of Analysis. $13^{\text {th }}$ edu. Association of Official Analytical Chemists, Washington, D.C.

Abd El-Halim, A.Z.; A.M. Rammah; M.A. El-Nahrawy and G.S. Nikhiel (1998). Evaluation of alfalfa cultivars in sandy and calcareous soils. Egypt. J. Plant Breed, 2: 35-42.

Abd El-Halim, A.Z.; I.A. Hanna and Y.A. Mohamed (1992). Productivity and forage quality of some alfalfa cultivars on newly reclaimed sandy soils. Egypt. J. Appl. Sci., 9: 407-427.

Abd El-Rady, W.A. (2018). Forage and seed yields stability of some alfalfa genotypes under different environments. M.Sc. Thesis, Fac. of Agric., Assiut Univ., Egypt.

Abdel-Galil, M.M. and N.M. Hamed (2008). Evaluation of yield potential, genetic variances and correlation for nine cultivars of alfalfa under the New Valley environment. J. Agric. Sci. Mansoura Univ., 33: 4771-4776.

B.A.S. (2018). Bulletin of the Agricultural Statistics. Arab Republic of
Egypt. Ministry of Agriculture and Land Reclamation Economic Affairs Sector, p. 167.

Cakmakci, S.; B. Aydinoglu; M. Arslan and M. Tetik (2004). Effect of different plants species and different sowing dates on forage yield, grazing capacity and estimated carcass weight in the continental climate zones. Turkish J. of Veterinary and Animal Science, 28: 701-705.

Geweifel, H.G.M. (1997). Seed and forage productivity of alfalfa cultivars as affected by row spacing and $\mathrm{K}$ fertilization under soil conditions. Zagazig J. Agric., Res., 24: 22.

Gomez, K.A. and A.A. Gomez (1984). Statistical Procedures for Agricultural Research. Jon Wiley and Sons, New York, $2^{\text {nd }}$ ed.

Hamd Alla, W.A.; B.R. Bakheit; A. Abo-Elwafa and M.A. El-Nahrawy (2013). Evaluate of some varieties of alfalfa for forage yield and its components under the New Valley conditions. J. of Agroalimentary Processes and Technologies, 19: 413-418.

Hamd Alla, W.A.A. (2012). Effect of selection for root characteristics on forage yield of alfalfa. M.Sc. Thesis, Faculty of Agric., Assiut Univ., Egypt.

Ibrahim, H.I.; N.M. Hamed and M.M. Abdel-Galil (2014). Genetic behavior of some alfalfa cultivars under New Valley conditions. Egyptian Journal of Plant Breeding, 18: 495-507.

Julier, B.; C. Huyghe and C. Ecalle (2000). Within- and amongcultivar genetic variation in alfalfa: forage quality, morphology and yield. Crop Science, 40: 365-369.

Mousa, M.E.; I.A. Hanna and Z.M. Marei (1996). Evaluation of some alfalfa (Medicago sativa L.) cultivars for growth and yield in sandy 
soil at North East of Egypt. Zagazig J. Agric. Res., 23: 29-49.

Mueller, S.C. (2005). Considerations for successful alfalfa stand establishment in the central San Joaquin Valley. Proceeding California Alfalfa and Forage Symposium 12-14 December, 2005.

Oushy, H.S.; M.M. Abdel-Galil and N.M. Hamd (2007). Performance of local and exotic alfalfa cultivars under different environmental conditions in Egypt. Egypt. J. Agric. Res. 85: 2201-2217.

Popovic, S.; T. Cupic; S. Grljusic and M. Tucak (2006). Use of variability and path analysis in determining yield and quality of alfalfa. Proceeding of XXVI of the EUCARPIA Fodder Crops and Amenity Grasses Section, Perugia, Italy, 95$99 \mathrm{p}$.
Saeed, M. and C.A. Francis (1984). Association of weather variables with genotype $\mathrm{x}$ environment interaction in grain sorghum. Crop Sci., 24: 13-16.

Sengul, S. (2002). Yield components, morphology and forage quality of native alfalfa ecotypes, on line Journal of Biological Science, 2: 494-498.

Tuckak, M.; S. Popovic; T. Cupic; S. Grljusic; S. Bolaric and V. Kozumplik (2008). Genetic diversity of alfalfa (Medicago spp.) estimated by molecular markers and morphological characters. Period Biol., 110: 243-249.

Walker, T.T. (1960). The use of a selection Index technique in the analysis of progeny row data. Emp. Cott. Gr. Rev., 37: 81-107. 
استجابة محصول العلف لمواعيد الزراعة الخريفي و الربيعي في البرسيم الحجازي

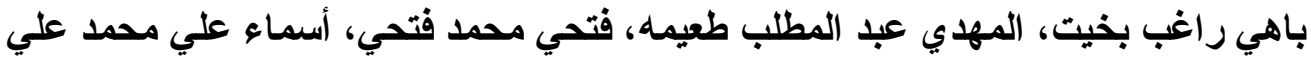

قسم المحاصيل - كلية الزر اعة - جامعة أسيوط

أجري هذا البحث في مزرعة قسم المحاصيل - كلية الزر اعة - جامعة أسيوط، لدر استة

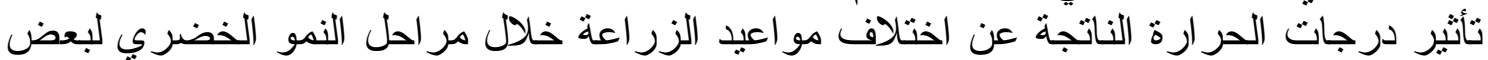

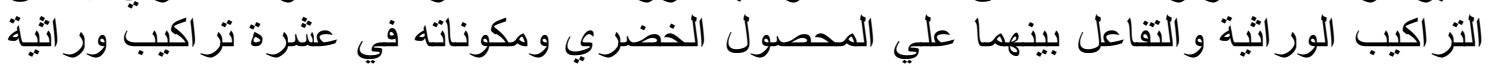



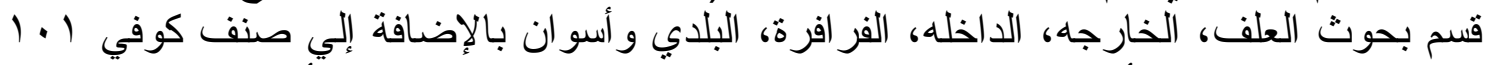

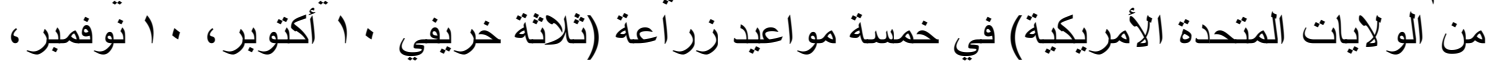

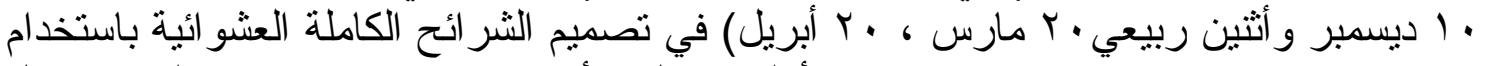

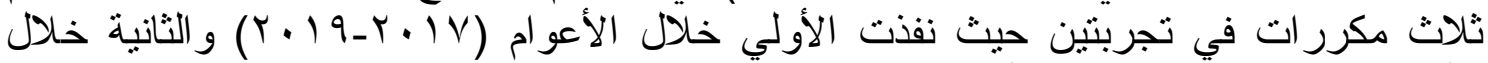

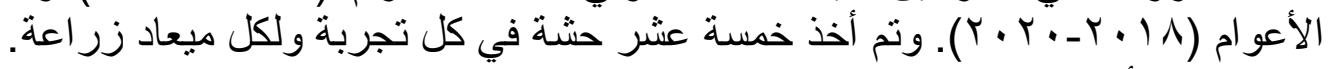
وكان أهم النتائج المتحصل ون عليها كما يلي:

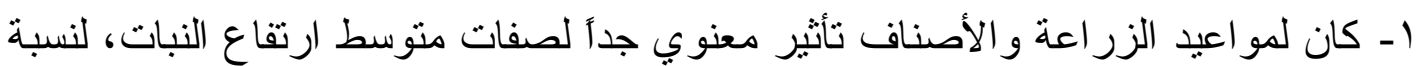

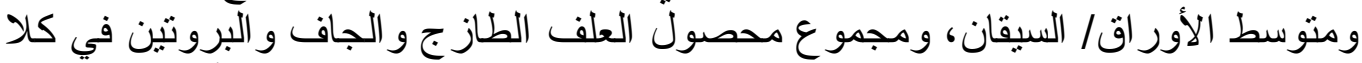



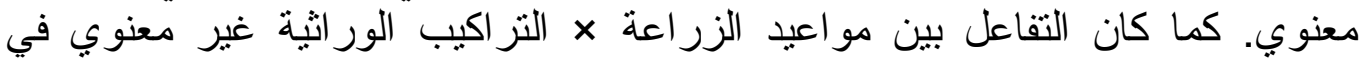

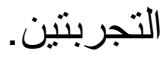

r- تم الحصول علي أعلي ارتفاع للنبات لليعاد الزراعة في شهر مارس و أبريل في كلا



$$
\text { وديسمبر. }
$$

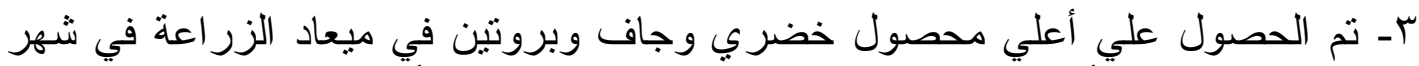

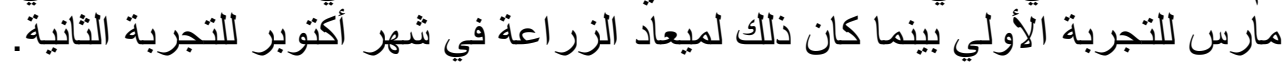

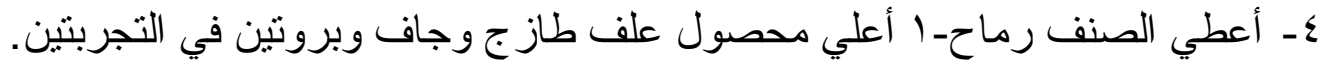

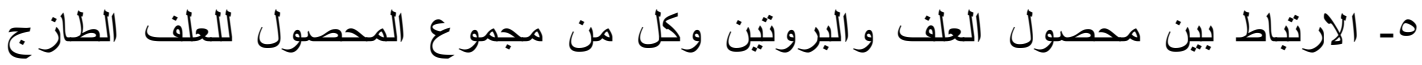

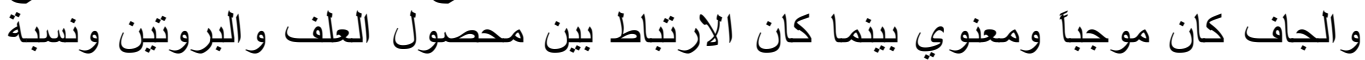
الأوراق إلي السيقان سالبأ في كلا التجربنين. 